\title{
STUDENTS' ABILITY IN USING SUBJECT-VERB AGREEMENT
}

\author{
N. Erna Marlia Susfenti \\ UIN SMH Banten \\ Serang, Indonesia \\ erna.marlia@uinbanten.ac.id
}

\begin{abstract}
This research was aimed at investigating the Students' Ability in Using Subject-Verb Agreement and the error made by the students in using subject-verb agreement. The writers was used the deductive approach to minimize the errors on learning grammar process and improving their ability in using subject-verb agreement. The students ability in using subject-verb agreement was categorized into the poor categories with 17 students and followed by very poor categories with 8 students from 34 students are there in the class. This research also found some causes of the students error while learning the grammar structure especially subject-verb agreement. The error occurred while learning subject verb agreement was on intralingua error like, false analogy and misanalysis.
\end{abstract}

Keyword: students' ability, subject-verb agreement, and cause of error.

\section{INTRODUCTION}

Language is the method or tool of communication in social life either spoken, written, or gesture. When people use language, the meaning that received will be more than what is heard from the explicit utterances. Their gesture, intonation, and also expression, will influence the way the speaker talks to send a message and implicit information within the message. Background, location, and time also play the importan rules when the communication made.

There are many languanges in the world, one of them is English.English is an international language which taught in all level of education in Indonesia. All students from elementary until university level are studying English. Students will have good ability in using English when they can use lingusitic competence within communication process. The ability to pronounce or spell the words including how to use stressing and intonation, how to use diction an expressions, and also how to use grammatical structure is the guarantee that they can communicate properly.

Grammar is the important thing of language. It makes the students know how to make good sentences and express ideas and meaning. By understading grammar the students will tend to write and speak English well. According to Corder (1988:133), learning the grammar of the language is acquiring the ability to produce grammaticaly acceptable utterances in the language. Thus, even some recent approaches to language teaching which 
emphasise its communixative aspect do not ignore the relevance of grammar. ${ }^{1}$

Grammar has many material to learn, it has big scope of lesson. One of the material that must be teach is about subject and verb agreement. When the subject and the verb are match each other is called subject and verb agreement. The understanding of this material is very important, because both subject and verb are the elements of the sentence. Eventhough, sometimes found that the students did not use the grammatical roles when making the sentence. Its make the readers confuse and misunderstand with the sentences that made by the students.

There are some kind of grammatical error, the one that frequently found in students' writing was the subject and verb agreement. The error occurred when the students choosing the subject and the verb. Its mean if the subject was singular then the verb also must be singular, and conversely.

\subsection{Teaching Grammar}

The word Grammar traces back to the ancient Greek grammaticos, which means the "art of letters" to draw or to write.

\footnotetext{
${ }^{1}$ Tamilla Mammadova, Teaching Grammar to a Grammar Free Generation, Cambridge Scholars Publishing: 2019, p. 15.
}

${ }^{2}$ Grammar is the knowledge speakers have about the units and rules of their language; rules for combining sound into words (Phonology), rules of word formation (morphology), rules for combining words into phrases and phrases into sentences (syntax), an as well as the rules for assigning meaning (semantic). ${ }^{3}$ actually grammar has some various meanings and everyone undestands with their own way.

There are many ways to teach grammar. Both of it are deductive and inductive methods. Grammar can be taught either deductively or inductively. In deductive method the teacher first tells the rules to the pupils and then asks them to apply these rules to a given exercise. This is to proceed from general to particular. In deductive method, the teacher proceeds in the reverse way from particular to general. He presents certain examples before the pupils and then frames the rules with their help. Inductive method gives opportunity to the pupils to think and be active participants in the teaching process. In such a case examples must be taken from the textbook itself. As it appears, it is better to follow the

\footnotetext{
${ }^{2}$ Tamilla Mammadova, p.16

${ }^{3}$ Victoria Fromkin, Robert Rodman, and Nina Hyams, An Itroduction to Language, Boston: Wadsworth Cengage Learning, 2014. p. 9
} 
inductive rather than the deductive method in teaching grammar. ${ }^{4}$

$$
\text { Supported by Thornbury }
$$

deductive approach (rule-driven) starts with the presentation of a rule and is followed by examples in which the rule is applied. Its mean the teacher is introduced and explained the rule of the grammar first, and then the students usually complete grammar exercises to become more familiar with the pattern. Further, he explained that an inductive approach (rule-discovery) starts with some examples from which a rule is inferred. This approach more focuses on how the way the students discover their own learning process. The teacher would present the students with a variety of examples for a given concept without giving any explanation about how the concept is used. At that time, the students see how the concept is used, it is expected that they will notice how the concept is to use and determine the grammar rule. Finally, the teacher explains the grammar rule as a final check that the students understand the concepts.

\subsection{Subject - Verb Agreement}

Subject-verb agreement is suitability between the subject and verb. If the subject is singular then the verb must be singular. According to Sargeant (2007) subject and verb agreement occurred when the subject and the verb match each other. According to Hornby in Mas'ud, agreement (concord) is agreement between the subjects with its verb (predicate). Similarly, by Leech, who states that concord (is also called agreement) in the most general terms, concord is a relation between two elements such that they match one another in terms of some grammatical feature (Leech, 2006). The subject - verb agreement can describe with the example bellow:

She (singular subject) eats (singular verb) bananas for breakfast.

They (plural subject) climb (plural verb) the mountain.

I (singular subject) was (singular verb) born on Wednesday

Rina and Rani (plural subject) were (plural verb) born on Monday

My father (singular subject) has (singular verb be) gone to Bali

My sisters (plural subject) have (plural verb be) gone to Bali

Every tense has each different

${ }^{4}$ Neena Dash, Teaching English as an Additional Language, New Delhi: Atlantic, 2007. p. 69 
were the examples of simple present tense, the pattern of this tense is adding s/es to the verb of the singular subject like in the example number 1 . While, the 3 and 4 were the examples of past continues which use was for the singular subject and were for the plural subject. Then, the 5 and 6 examples were from present continuous; use has if the subject is singular and have if the subject is plural.

From the explanation above, it is clear that subject-verb agreement is concord between subject and agreement. If the subject is singular the verb also must be singular, then if the subject is plural the verb also plural. The subject-verb agreement needed because without both of them the sentence can not complete.

\subsection{Cause of Error}

Based on Carl James there are four major categories of error that made by English learner. First, mother tongue influence: Interlingua error, this kind of error means the impact of the first language toward the second language they are trying to learn. It occurred when someone speak English with Javanese or Sundanese accent. Second, target language causes: Intralingua error, the problem of this kind of error is the
Target Language (TL) itself. When the learners ignore the TL form on any level and of any class can do either of two things: either they can set about learning the needed item, engaging their learning strategies or they can try to fill the gap by resorting to communication strategies. These are the learning strategy-based errors: 1). False analogy, 2). Misanalysis, 3). Incomplete rule application, 4). Exploiting redundancy, 5). Overlooking co-occurrence restriction, 6). Hypercorrection, and 7). Overgeneralization. Third, communication strategy-based error, this kind of error consist; holistic strategies and analytic strategies. Forth, induced errors, induced errors refer to learner errors that result more from the classroom situation. They are being misled by the ways in which the teachers give definitions, examples, explanations and arrange practice opportunities. ${ }^{5}$

\section{METHOD}

The method of the study was descriptive qualitative. The source of the data was the students of non-English department UIN Sultan Maulana Hasanuddin Banten that consist of 34 students in a class. The writer gives the test

\footnotetext{
${ }^{5}$ Carl James, Errors in Language Learning and Use, London; Longman, 1998. p. 179
} 
and questionnaire about their ability in using subject-verb agreement and cause the error while learning it.

\section{DISCUSSION}

Based on the learning process, the writer as a teacher use the deductive approach that relate with teaching English grammar especially subject-verb agreement. Deductive approach is the teacher-centered learning, thus the teacher starts with the presentation of a rule and followed by the examples in which the rules is applied. In every meeting, the writer prefers to explain the structure or the rules of grammar rather than asked the students to search their self. After explained the grammar rules the teacher gave the exercises to the student to know either they understand the material or not. The teacher also tells the students to be aware of using subject verb agreement. They have to know that every different tense also have different subject-verb agreement. Giving exercise to the students will let them know the different usage of subject-verb agreement.

According to Ellis (2002) the teacher can drill the students' ability in grammar by using grammar practice to raising students' consciousness. In this study the teacher considers grammar practic 
e to be the opportunity for the students to practice the structures. This means that the students can practice under the controlled conditions and the exercise attempt to encourage learners to see how grammatical structures can be used in reallife situations. While the teacher not only used grammatical practice but also to raising consciousness through grammar practice, means that after the students get the exercise and the students have misused the grammatical structure the teacher gives the students classification either in the form of more exercises and explanation again.

In conclusion the teacher used deductive approach in teaching grammar as follow. First, the teacher gives the clear explanations about the material, in this case about the rules of grammar especially the use of subject-verb agreement. Then, the teacher checked the students' understanding by giving exercises. Finally, if it possible the teacher looking for the answer sheet in order to give feedback if still found misused.

Based on learning process the writer can conclude the result of the learning as follow; based on counting the values of students' subject-verb agreement test, there was one student got 87,2 students got 80,6 students got 70,8 students got 60,9 students got 53 , and 8 students got 45 points.
Here is the table of the score:

\begin{tabular}{|c|l|l|l|}
\hline No & $\begin{array}{c}\text { Level of } \\
\text { Ability }\end{array}$ & $\begin{array}{c}\text { Frequenc } \\
\mathbf{y}\end{array}$ & $\begin{array}{c}\text { Percentag } \\
\text { e }\end{array}$ \\
\hline 1 & $\begin{array}{l}\text { Excellen } \\
\mathrm{t}\end{array}$ & 1 & $3 \%$ \\
\hline 2 & Good & 2 & $6 \%$ \\
\hline 3 & Fair & 6 & $18 \%$ \\
\hline 4 & Poor & 17 & $51 \%$ \\
\hline 5 & Very & 8 & $23 \%$ \\
\hline $\mathbf{l}$ & Poor & & $\mathbf{1 0 0} \%$ \\
\hline
\end{tabular}

The table shows that the majority of the students with $51 \%$ included to the poor categories in using subject-verb agreement, followed by the very poor categories with $23 \%$, fair $18 \%$, good $6 \%$, and the excellent got less score with $3 \%$. While, according to the students' opinion in using subject verb agreement, $30 \%$ (10 students) said that felt very difficult to use subject and verb agreement, 60\% (20 students) said it was difficult, 9\% (3 students) said it was quite easy, and 3\% (1 student) said it was easy. But none of them said that was very easy.

The reason of the students' difficulties in using subject-verb agreement were; they did not understand the meaning of the sentence, confusing when the tense 
changes, or the sentences changed from active to passive which make the subject also different, like: they have taken the injured boy to the hospital (active) will become the injured boy has been taken by them to the hospital (Passive), but many students said the injured boy have been taken.... They rivet on the first sentence which using have because the subject was they; they forget that the boy was singular and only match also with singular verb or verb be, in this occasion it should use has.

\section{CONCLUSION}

Based on the research findings and discussion, it can be concluded that the use of deductive approach by the teacher can raising students' understanding in using subject verb agreement. The teacher aware how to teach grammar to the student effectively, especially in teaching subjectverb agreement which has different linguistic features with their mother tongue

Based on the data it has known that the ability of students in using subject-verb agreement was poor. It proved with the score of the student that included to the poor category. Some of the students made the error when choosing the suitable verb for the subject. It will be the motivated for the teacher to improve their approach in order to make the learning more effective and easy to understand. However, for the students it is suggested them to have more exercises in learning subject-verb agreement. If they found some difficulties when learning themselves, then they can ask to the teacher.

Based on the error occurred when they learning this subject-verb agreement, hopefully the students can differentiate the different using of grammar pattern or structure. Finally, for the future researchers, they should have good method and also doing deep researching and observing techniques.

\section{REFERENCES}

Brown, H. Douglas. (2007). Principles of language learning and teaching: An interactive approach to language pedagogy (3rd Ed.) . New York: Pearson Longman, Inc.

Dash, Neena. (2007). Teaching English as an Additional Language. New Delhi: Atlantic.

Ellis, R. (2002). Grammar Teaching Practice or Consciousness-Raising? In J. Richards \& W. Renandya (Eds.), Methodology in Language Teaching: An Anthology of Current Practice (Approaches and Methods in Language Teaching, pp. 167-174). Cambridge: Cambridge University Press. 
Volume 3 No. 2, August 2020

Fromkin Victoria, Robert Rodman, and Nina Hyams. (2014). an Introduction to Language. Boston: Wadsworth Cengage Learning

James, Carl. (1998). Errors in Language Learning and Use. London: Longman.

Mammadova, Tamilla. (2019). Teaching Grammar to a Grammar Free Generation. Cambridge Scholars Publishing Mas'ud, Fuad. (1996). Essentials of English Grammar a Practical Guide (2nd ed). Yogyakarta: BPFE, Sargeant,

Howard. (2007). Basic English Grammar for English Language Learners. Unite State: Saddleback Educational Publishing.

Thornbury, S. (1999). How to Teach Grammar. New York: Pearson. 